\title{
E-Employment? College Grad Career Building In A Changing And Electronic Age
}

\author{
Susan Eisner, Ramapo College of New Jersey, USA
}

\begin{abstract}
The unusual nature of the current economic environment combined with changing labor market demographics heightens the importance to those engaged in employment activity of utilizing methods that fulfill their needs. But electronic technology is transforming available employment methods. How can career building and recruiting best be sustained in today's continually changing and ever-more electronic age? This paper identifies current practices employers, prospective employees, and career service providers seeking to optimize contemporary employment methods can consider.
\end{abstract}

Keywords: Career Building, College Career Services, College Graduates, Economy, Electronic Career Practices, Employment, Generation Y, Great Recession, Human Resources, Online Career Services, Recruiting, Technology, Unemployment

\section{INTRODUCTION}

W

hat has been commonly referred to as the recent "Great Recession" unsettled many typical employment trends, and created new challenges for employers and would-be employees. By the end of 2009, U.S. unemployment's steady climb during the recessionary period that began in December 2007 had reached 10\%, doubled its pre-recession rate (Employment Situation Summary, 2010), and reached its highest level in 17 years (Aversa, 2009). In addition to the 15.3 million people unemployed at that two year 2009 marker, 9.2 million were working part time who wanted to be working full-time. Another 2.5 million were not counted as unemployed but wanted to work. Of these, 1.6 million had looked for work in the past year but not in the past month, and 929,000 had stopped looking for work feeling it futile to seek employment (Employment Situation Summary, 2010).

The unemployment rate among college educated workers continued to be lower than for those who had had less education. At the end of $2009,4.7 \%$ of those over age 25 with college or higher degrees were unemployed, while $15.7 \%$ of those over age 25 who had not completed high school were unemployed (Employment Status, 2010). But that unemployment rate for those with college or higher degrees had increased from $3.3 \%$ a year earlier, and from 2.1\% at the Great Recession's start (Educational Levels, 2009). Moreover, the 2009 unemployment rate for recent college graduates (those aged 27 or under) had averaged $7.1 \%$ by October of the year. That rate had doubled since the Great Recession's start, and was the highest yearly average in its 30 year tracking history (Kleinfield, 2009).

Corporate recruiters describe a resulting job market that is more difficult for recent college graduates. Recruiters point to that job market as one in which recent graduates look for work that is ever scarcer, while competing with ever more unemployed workers who have comparatively stronger qualifications (Shin, 2009). The National Association of Colleges and Employers (NACE) predicted the job market for 2009 college graduates would be the worst in 6 years, and that those with a GPA under 3.0 would likely be screened out. It reports relevant work experience, leadership, communication, work ethic, initiative, ability to work in teams, and initiative to be all the more important for new graduates seeking employment (What College Grads Can Expect, 2009). NACE's Spring 2009 Job Outlook Update found 91\% of employers surveyed planning to decrease the number of new college graduates they would hire that year, two-thirds planning to hire no new college graduates or fewer than they had hired the year before, and an overall predicted decline of at least $22 \%$ fewer new college graduates hired in 2009 than in 2008. NACE expects the fall off in such hiring to continue for the class of 2010 , with only $13 \%$ of employers expecting to hire more new graduates that year than they hired in 2009. 
The Economic Policy Institute estimates that more than 9 million U.S. jobs will need to be added to return employment to its pre-Great Recession levels (Labor Day by the Numbers, 2009). But only a few years earlier, the U.S. was considered to be at nearly full employment (US Near Full Employment, 2006). The unusual nature of the current economic environment thus makes future labor force projections uncertain. That uncertainty heightens the importance to employers, potential employees, and career service providers of utilizing methods that sustain employment needs and interests. But electronic technology is transforming available career building and recruiting methods. How can career building and recruiting best be sustained in today's continually changing and ever-more electronic age? What practices are currently in use that those engaged in employment activity can consider?

\section{CORE TRENDS}

Central to optimizing employment methods is consideration of labor market trends. Demographic shifts have predicted for some time a coming "brain drain" in the U.S. workforce (Present and Future Job Market, 2006; SHRM, 2008). The populous Baby Boomer Generation is reaching retirement age, and Generation X (Gen X) that follows it chronologically is far fewer in number and so cannot fully replace Baby Boomer workplace presence (Dohn and Shniper, 2007) ${ }^{1}$. Simultaneously, contemporary employers increasingly need workers who have higher levels of education (SHRM, 2008; Uhalde and Strohl, 2006). As a result the recruitment and retention of college educated workers, and those of Generation $\mathrm{Y}^{2}$ (Gen Y) that follows Gen X chronologically, has been widely described as an imminent priority for business (SHRM, 2008; Hira, 2007).

Concurrently, the placement upon graduation of today's college students into jobs that begin their career ladders increasingly depends upon employment methods that prior generations may have contemplated as science fiction "brave new world" activity, but that are becoming industry standard. Operative "e-employment" practices now include companies' usage of their websites to capture interest and attention of potential candidates (Borstorff et. al., 2007), third-party websites as initial employment portals (Borstorff et. al., 2007), standardized on-line employment applications (Stafford, 2007), employment introductions and interviewing mediated by telephone or video (Video Resumes, 2007), computerized pre-employment performance appraisal (Piotrowski and Armstrong, 2006), third-party social networking sites both for information collection about applicants (Millard, 2007) and entrée to past employees (Cappelli, 2001) or potential candidates not actively seeking work (Koc and Collins, 2008), and incentives to current employers who help locate viable candidates through online activity (Fountain, 2005). Although in time these practices may well become the new normal, the shift now underway may seem seismic to those accustomed to more traditional in-person, hard copy employment practices - including some of those from whom today's largely Gen Y college students seek career building guidance.

\section{OPPORTUNITIES AND CHALLENGES}

Already some are describing creation of a virtual global labor market mediated by electronic technology in which labor talent can access best career opportunity, opportune employers can access best talent, and savings in time and money for employer and candidate are achieved (Borstorff et. al., 2007; Fountain, 2005; Cappelli, 2001). Others describe "naïve" expectations of employers and candidates engaged in such e-employment activity (Koc and Collins, 2008). Resulting quandary they discuss include inefficiency when technology heightens potential employment quantity rather than quality (Fountain, 2005), reliance on expedient screening that may falsely predict job performance (Scroggins et. al., 2008; Piotrowski and Armstrong, 2006), fallout from employment depersonalization (Borstorff et. al., 2007; Piotrowski and Armstrong, 2006), cavalier informalization, and the prospect of recruitment transition from HR to Business Development function (Cappelli, 2001). Concerns have also been raised about potential legal liability arising from invasion of privacy (Borstorff et. al., 2007), abridgement of confidentiality/transparency norms (Piotrowski and Armstrong, 2006), and employment decisions influenced by information gathered online (The Internet Brings Risks, 2006). Additional concerns have been raised regarding possible equal employment opportunity violation due to insufficient Equal Employment Opportunity Commission rules guiding e-employment activity (Sprague, 2007), potential disparate impact of selection processes dependent upon computer access and ability (Borstorff et. al., 2007), overuse of employee referral programs resulting in demographic replication of the existing workforce (The Internet Brings Risks, 2006), online screening activity that discriminates through illegitimate or invalid testing (Cappelli, 2001), and access to and use of information not otherwise available about protected characteristics (Video Resumes, 2007). 
At the same time, college students readying to begin career searches tend to be of Gen Y, the most technologically literature generation yet (Allen 2004). These young people not only frequent technology, but are immersed it in. They rely on technology to get information, and use it to seek companies and people with whom they share values (Hira, 2007). Through multi-tasking, members of Gen Y manage to spend more hours in virtual reality each day than there are hours in that day (Weiss, 2003). So today's college students tend to be comfortable with and present in the digital world in which electronic employment functions. Their presence encompasses the portals formally labeled as career sites, as well as the social networking sites in which they informally interact with personal "friends" but which are publicly available to potential employers seeking to screen (Workers Naïve, 2008; Sprague, 2007).

Studies report the majority of young people enter college eager for career guidance (Noel-Levitz, 2008, 2007), and that their generation tends to lack career direction (Chao and Gardner, 2007). Employers report being confounded by Gen Y's apparent tendency to find career direction by moving from one job to another. They describe this as "job surfing" - Gen Y's tendency to behave in the work world as they do in the virtual one. Gen Y tends to move from job to job in the real world, engaging in sequential employment, as they have habitually clicked through sites sequentially on the Internet (Chao and Gardner, 2007). As a result, some describe Gen Y as even more of a challenge to retain at work than to hire. Those between the ages of 22 and 32 today have already averaged seven job changes (For New College Grads, 2008).

Thus, the college student seeking fulltime gainful employment and the employer seeking to inoculate against pending brain drain appear to have a common interest in locating each other. Technology is an emerging, growing, and complex factor in pursuing that interest. It presents opportunities and challenges involving practices and choices that are only beginning to be addressed.

\section{PURPOSE AND METHOD}

This paper seeks to contribute to the business and management literature, practice, and education by exploring a timely topic: Building careers of college graduates in a changing and electronic age in which needs and practices of both employer and candidate are evolving, and in which employment strategies of both increasingly involve electronic technology. A literature review has consulted more than 100 academic and practitioner sources published within recent years. Literature from several recent years was intentionally reviewed and included. Given the unusual nature of the current environment, data from any one year might be non-reflective of longer lasting trends.

Additionally, primary research has visited college career websites, third party career websites, and websites of companies listed among "the best" employers for new college graduates. Moreover, a pilot study of practitioners has been conducted to sample the extent to which and how electronic employment is operative in their companies. From these sources current practices that employers, prospective employees, and career service providers can consider are identified and implications are discussed.

\section{EXTENT OF E-EMPLOYMENT ACTIVITY}

Data on duration, nature, and quantity of e-employment activity suggest that it is neither a passing fad nor in little use. Papers published in 2001 (Cappelli) and 2007 (Borstorff et.al.), for instance, both report more than 90\% of Fortune 500 companies engaged in online recruiting. More than $92 \%$ of Fortune 500 companies have a website designated for careers, and more than $90 \%$ of job candidates review a company's website before applying for work. More than 4 million Americans conduct online job searches every day (Borstorff et. al., 2007). Employers spend some 6 billion dollars annually for online job-boards in 40,000 sites (Babcock, 2007). In 2001 Cappelli reported that the ability to consider many qualified candidates, assess them quickly, and contact the top choice instantly can cut 15 days off a typical 43 day hiring timeframe, at one-twentieth the cost of traditional want-ad hiring. By 2007 Borstorff et. al. found that e-career building can reduce replacement costs, typically estimated at one-third of salary, by an estimated $20-30 \%$. 
The majority of the U.S. population, and the majority of U.S. working age adults, was using the Internet by 2001 (Fountain, 2005). Those who search for work online tend to be those seeking work most intensely. There they can find literally thousands of websites seeking to match workers with jobs through online databases, classified ads, job postings, and corporate websites through which they can apply for multiple positions and relatively quickly. Similar opportunity exists for employers who with such technology can search and evaluate many potential applicants. The largest career sites are for-profit companies that provide full-service recruiting and screening services to employers who seek them (Fountain, 2005). Some 51\% of new hires in 2005 came from Internet sources; a quarter of new hires came through corporate career websites (Borstorff et. al., 2007).

Uses of websites for screening purposes are wide-ranging. The U.S. Department of Education reports, for example, that there are more than 5,000 third party websites assessing skill level and issuing credentials if earned. By 1999 those websites had already performed 3 million skill assessments (Cappelli, 2001). Additionally, threequarters of employers regularly search online as they check backgrounds; that online search activity includes social networks and blogs (Millard, 2007). Screeners are likely to find Gen Y there. Nearly 83\% of the 19,000 U.S. students reporting to NACE's 2008 graduating student survey reported having a profile on social networking sites (Koc and Collins, 2008).

Table 1 reports monthly U.S. demographic usage for January 2009 recorded by Quantcast ${ }^{3}$ of representative websites frequently mentioned in e-employment literature. Those 18-34 were the largest age group of users for all of the sites except for careerbuilder.com where it tied with 35-49 year olds for the largest age group of users, and linkedin.com whose target demographic is mid-career professionals. Given that $70 \%$ of all jobs are found through networking (Collegerecruiter.com, 2006), potential candidate access to literally millions of people through such sites is of particular note. Also of note is the continued growth in usage of designated job search and career development sites suggested by comparison of 2008 and 2009 data. The Associated Press reported a 20\% increase in usage, with 49.7 million using such sites in January 2009 as compared with 41.5 million one year earlier (Checking Job Sites Increases, 2009).

Table 1: Website Demographics - Monthly U.S. Usage January 2009

\begin{tabular}{|l|c|c|c|}
\hline \multicolumn{1}{|c|}{ Website } & Total U.S. Users & \# 18-34 Year Old Users & \% 18-34 Users \\
\hline Facebook.com & $65,600,000$ & $30,832,000$ & 47 \\
\hline Myspace.com & $67,900,000$ & $30,555,000$ & 45 \\
\hline Careerbuilder.com & $12,600,000$ & $4,788,000$ & 38 \\
\hline Monster.com & $11,800,000$ & $4,602,000$ & 39 \\
\hline Linkedin.com & $10,800,000$ & $3,240,000$ & 30 \\
\hline Vault.com & 403,000 & 157,170 & 39 \\
\hline Collegegrad.com & 260,000 & 135.200 & 52 \\
\hline
\end{tabular}

While e-employment does not appear to be a fad nor unused, traditional employment methods appear to be in wide use as well. A study of 151 Fortune 1000 companies found the majority saying they rely on traditional recruitment and personnel selection techniques rather than online assessment instruments (Pitrowski and Armstrong, 2006). The majority of employers replying to the 2008 NACE Job Outlook survey reported favoring "high-touch" methods such as on-campus recruiting, internship/coop, and employee referral, rather than Internet usage, for recruiting new college graduates. On a scale of 1 (low) to 5 (high) respondent employers rated the effectiveness of such traditional employment methods to be on-campus recruiting 4.2, organization's internship program 4.2, employee referrals 4.0, organization's coop program 4.0, and career/job fairs 3.8 (Koncz and Collins, 2008).

One year later, though, the Job Outlook Spring Update reported budget cuts in employers' college relations programs and a sharp usage drop by employers of the traditional methods they have rated as highly effective. Specifically, employers reported a significant decline in their overall on-campus recruiting activities of career job fairs, on-campus interviews, and employment information sessions on campus, as well as reduction in e-employment job posting on college websites (NACE, 2009). Moreover, NACE reported a 21\% decline in internships and $11 \%$ drop in coop positions available to college students for 2009 (Hiring Down Salaries Up, 2009). 


\section{PILOT STUDY RESULTS}

To better understand the extent to which and how employment techniques are used by contemporary employers, a pilot study of practitioners was conducted for this paper. A 2-page questionnaire was constructed containing various traditional and electronic employment methods identified in the literature review. Respondents were queried in the fall of 2008 regarding the extent to which the various employments methods, reported on below, are operative in their companies. Seventeen practitioner respondents completed the survey; an additional practitioner by request instead had a 1-hour telephone interview.

Ten of the respondents who completed the survey identified their company's industry. The industries they represent are automobile (2), electronics, financial services, insurance, law, information technology, pharmaceutical, photography, and transportation. Table 2 contains the self-identified demographics of the 17 survey respondents.

Table 2: Respondent Demographics

\begin{tabular}{|c|c|c|c|c|c|c|}
\hline Company Size & Large & Medium $19 \%$ & Small & $6 \%$ & & \\
\hline Department & Corporate $59 \%$ & HR $\quad 18 \%$ & Line & $6 \%$ & Staff not HR $\quad 6 \%$ & Other $12 \%$ \\
\hline Management Position & Senior $\quad 41 \%$ & Middle & Lower & $6 \%$ & Non-management $18 \%$ & \\
\hline Age & $55+$ & $45-54$ & $33-44$ & $12 \%$ & $22-32 \quad 24 \%$ & $22-$ \\
\hline Gender & Female & Male & & & & \\
\hline
\end{tabular}

Respondents were asked to use a scale of 1 (low) to 4 (high) to report the extent to which a candidate's possession of important workplace skills is determined in their companies by 24 specific traditional and electronic methods used in several categories of employment modalities: application form, cover letter, interview, observation, portfolio/sample, reference, resume, and testing.

Table 3 summarizes survey responses, which are detailed in Appendix A. Of the 24 specific methods respondents reported on, the majority of respondent report very high use (4) at their companies of 5 methods: observation, interview, resume online, references on paper, and resume on paper. All of those except resume online are traditional methods.

Most respondents report high (3) or very high (4) use at their companies of 19 of the methods. Use of the first 8 of the highly used methods (interview in person through references on paper) is reported to be high or very high at their companies by more than three-quarters of respondents. These are a mixture of traditional and electronic methods.

The majority of respondents report very low (1) or low (2) use at their companies of 5 of the methods. All methods reported to be in low or very low usage are electronic, and involve interviewing or referencing by nontraditional means.

Table 3: Extent to Which (\%) Respondents' Companies Use the Methods

\begin{tabular}{|l|l|}
\hline $\begin{array}{c}\text { Method in very } \\
\text { high use (rated 4) }\end{array}$ & \multicolumn{1}{c|}{$\begin{array}{c}\text { Observe in person (85.71), interview in person (81.25), resume online (62.50), references on } \\
\text { paper (57.14), resume on paper (50.00) }\end{array}$} \\
\hline $\begin{array}{l}\text { Method in high use } \\
\text { (rated 3 or 4) }\end{array}$ & $\begin{array}{l}\text { Interview in person (100.00), resume online (93.75), observation in person (92.85), resume on paper } \\
(85.71), \text { portfolio/sample on paper (84.62), portfolio/sample online (84.61), portfolio on CD (80.00), } \\
\text { references on paper (78.57), testing online (70.00), testing through simulation (66.66), application } \\
\text { online (64.28), interview by phone (64.28), testing on paper (63.63), references by phone (61.53), } \\
\text { references by email (58.34), application on paper (58.34), cover letter online (57.14), observation by } \\
\text { video (58.33), cover letter on paper (53.84) }\end{array}$ \\
\hline $\begin{array}{l}\text { Method in low use } \\
\text { (rated 1 or 2) }\end{array}$ & $\begin{array}{l}\text { Interview by e-mail (75.00), interview by instant message (73.72), references by instant message } \\
(70.00), \text { references by video (63.63), interview by video (53.84) }\end{array}$ \\
\hline
\end{tabular}


Responses regarding use of employment modalities overall suggest the primary importance of the interview, especially in person, consistent with the high importance also reported of observation in person. The resume also appears to be an important method both in traditional and electronic forms, as do portfolio/samples in both traditional and electronic forms. Referencing, especially on paper, appears to be important. Cover letter and application form appear to be currently somewhat less, but still, important employment methods at respondents' companies. Testing also seems to be an important method where it is used, but as it was the one modality for which fewer than 12 respondents reported usage in both traditional and electronic forms its current overall usage amongst companies is unclear.

Respondents were also asked the overall extent to which the above traditional and electronic employment techniques are used in making decisions by themselves/their companies, and by other U.S. companies. The majority reported equal use of traditional and electronic employment methods at their own companies (75.00\%), as well as at other U.S. companies $(71.43 \%)$. Those who did not report equal use of traditional and electronic employment methods were more likely to report that their own companies $(18.75 \%)$ and other U.S. companies (28.57\%) use mostly traditional methods. No respondents reported other U.S. companies using mostly electronic employment methods, and only 6.25\% reported their own companies using mostly electronic employment methods. These responses are consistent with responses regarding use of specific traditional and electronic employment methods reported from the secondary literature earlier in this paper.

The $18^{\text {th }}$ practitioner who participated in this pilot study through a telephone interview in lieu of survey works for a large company, in the business services sector, in a lower/middle management line position with hiring authority; he is in the lower demographic age group. His responses are particularly germane given his frequent involvement in hiring recent college graduates, his relative closeness in age to many of the candidates he reviews, his focus on the in-person interview which was identified as a highly salient method by survey respondents, and the extent to which his remarks illustrate in practice the contemporary employment environment the secondary literature points to.

A constant theme of this respondent's remarks was "concern with Gen Y." He describes Gen Y as lacking loyalty evidenced by frequently leaving for a better job after a year or so, needing instant gratification to be retained, being deficient in interpersonal skill, and having difficulty with time management. He uses the interview to probe for presence or absence of such attributes. Candidates he rates positively have been very involved at school and do many things, which he sees as indicating ability to multi-task. Further, positively rated candidates are able to speak to people and are engaged in networks, suggesting interpersonal ability. Technological skill of a candidate is of less concern to this respondent, as he feels most Gen Y candidates have such competence and those who do not can learn it. Of greater concern to him is that many being interviewed lack clear direction or decisiveness. He describes half the interviews he conducts as turning into teaching sessions in which he helps candidates determine a career direction, life goal, and specific objective through a series of questions and answers. Accordingly, he looks for candidates with a clear focused plan, goals that are not canned, and objectives that can be backed up. Being bright, which he feels GPA indicates, is a plus.

Lack of professionalism/savvy and protocol/etiquette by Gen $\mathrm{Y}$ candidates are additional deficits this respondent cites. He describes many coming to interviews without bringing their resume, having no pen or paper, not asking for a business card, having no questions to ask saying they have researched everything online, asking for salary in the first interview, being not appropriately dressed and groomed, and not sending a thank you note.

During the interview, this respondent probes for specific qualities relevant to the position. He perceives viable candidates for sales jobs, for example, as persuasive, competitive, driven to work harder than the next person, and able to handle rejection. To determine this, he probes for leadership positions held and background in sports.

This respondent's company is fast-growing. High performers can move up to management in at most a few years with an undergraduate degree. So leadership is probed for. Candidates are asked, for instance, whether they have coached and if they enjoyed the coaching or the recognition, with the former indicating intrinsic motivation this respondent seeks. He sees those aspiring to management just for money tending to fail, while those who care about others and can be trusted succeed. Situational questions are used to get at this, and examples are solicited. 
Thus, candidates are asked whether they have gone into a situation that was not working, at school or work, and if they fought to turn it around.

Before being interviewed, candidates take a half-hour personal STARS (situation, task, action, and result) assessment on line. A candidate's answers are scored against those of the company's most successful employees. Candidates scoring below 70 are not considered further.

When asked about referencing, this respondent said, "References don't happen at large companies. HR (Human Resource) gets verification mostly." When asked whether he searches online for background information on candidates, he said HR has instructed that doing so is illegal and should not be done due to online access to information about protected characteristics that should not be used in employment decisions. When then provided with more facts about usage elsewhere of online searches for information about potential hires he added, "But most of us do it informally anyway."

\section{CAREER RESOURCES PROVIDED BY COLLEGE/UNIVERSITY CAREER CENTERS}

The 2007 Career Service Benchmark Study conducted by NACE reported responses of some 600 4-year colleges and universities regarding career services they provide to their students. The services they reported offering most widely are traditional, "high touch," services facilitating face to face contact between student or alumni user and his/her potential employer. Virtually all reported offering career counseling by appointment (98\%), career fairs (94.4\%), on-campus interviews (94.1\%), assistance with finding internships (92.7\%), and workshops such as resume and interview preparation $(91.6 \%)$. At the same time, respondents indicated their widespread provision of electronic career services. Virtually all reported having a career services web site (98.8\%), and an online job posting system to help student or alumni users identify available jobs (95\%). Respondents also reported that those who use the high touch services offered, such as on-campus interviews and career fairs, are more successful at receiving jobs before graduation than those who do not. Further, NACE reported that employers consistently rate their internship programs and on-campus interviews as their most effective means for recruiting and hiring new college graduates (Luckenbaugh and Collins, 2007).

The NACE study points to a combination of traditional and electronic career services widely provided, and appears to emphasize the efficacy of traditional, high touch, aspects. But the study's $41 \%$ response rate raises a question as to whether non-respondent campuses might be offering a significantly lower or different level of career services. To further explore the type of career building support today's undergraduate business students can access at their schools, primary research was conducted for this paper. Representative websites of college and university career centers were reviewed. The sample of websites to be reviewed was constructed from recent rankings of best undergraduate business programs by Business Week (The Top Undergraduate Business Programs, 2008) and U.S. News \& World Report (Best Colleges Specialty Rankings, 2008). The Business Week list ranked the 96 schools whose programs it determined to be best; the U.S News \& World Report list ranked the 10 it determined to be best. Top ranked schools' career resources were chosen for review given the benchmark role their schools' stature indicates they hold.

To build a representative sample, schools were included if their undergraduate business programs were among the top 10 in either Business Week or U.S. News \& World Report rankings, in the middle range (\#43-52) of Business Week rankings, or in the bottom 10 (\#87-96) of Business Week rankings. The resulting sample contained 29 schools ${ }^{4}$. A review of career-related services available to undergraduate students at these colleges and universities, as described on their websites ${ }^{5}$, finds a robust array of resources. Most of the schools offer services that bridge academic, career (internship and full-time employment), and graduate school options. In doing so, most supply career support in the various stages ranging from counseling (identification of interests/skills and work that matches) to advisement (guidance) to planning/marketing (timeline/step-by-step career building) to placement (identification of and entrée to appropriate jobs). Most of the schools have intranets to which students and alum can sign on to access online counseling/advisement/placement opportunities, online databases and libraries, and information about events and other activities. Most of the schools supply tabs or links targeted to specific populations (e.g. alumni, employers, faculty, parents, and students) that focus on services most likely relevant to them. Most of the schools specify their career center policies ranging from job offers to cancellation/no show, clarify student users' rights and 
responsibilities, offer guidance on Internet usage, and provide tips on privacy protection when job searching. Most of the schools' career services span on- and off-campus opportunities, in wide geographic ranges. Most of the schools provide both traditional and electronic services and, as such, are virtually available to users all the time. Table 4 summarizes representative career resources likely to be found at most of the schools sampled.

Table 4: Career Resources Typically Found at Schools with Top Undergraduate Business Programs

\begin{tabular}{|l|l|}
\hline \multicolumn{1}{|c|}{ Traditional Career Resources } & \multicolumn{1}{c|}{ Electronic Career Resources } \\
\hline Advisement staff & Alumni database \\
\hline Calendar of events & Career resource intranet (log in) \\
\hline Career center & E-advisement \\
\hline Career library/bibliography/directories & E-credential/reference/portfolio service \\
\hline Career counseling staff & E-handouts \\
\hline Externship/job shadowing & E-network (searchable database) \\
\hline How-to handouts & E-recruiting (post resume and job search) \\
\hline Job fair/listing/recruiting & Interview guide/practice \\
\hline Mock interview & Links to external career/company/school sites \\
\hline Networking & Resources for specific populations \\
\hline Resume/cover letter sample & Resume/cover letter guide/construction \\
\hline Self-assessment inventory check-list/workbook & Salary information \\
\hline Student organization/professional association list & Self-assessment test \\
\hline Workshops/classes/speakers/events & Surveys on student/alumni employment \\
\hline
\end{tabular}

Comparison of career centers of highest ranked, middle ranked, and lowest ranked sampled schools suggests that availability of electronic resources can provide an equalizing opportunity to college/university career centers. The 14 top schools appear more likely than those lowest ranked to have well developed traditional career resources, but all 29 schools appear to provide a full range of electronic career resources. No other clear divergent pattern associated with a ranked category emerges. One top ranked school appears to be relatively lean in its provision of self-assessment testing, one middle ranked school appears to have less developed career services than some of the lowest ranked schools, while one lowest ranked school appears to provide an array of services so comprehensive that it describes them as being "second to none ${ }^{6}$."

When services provided by the career centers of the sampled schools are reviewed, the potential for accessibility provided by electronic resources is evident. Overall, career centers at the sampled schools tend to provide electronic access to four types of services: 1) third-party full-service career sites where users can plan, start, and build careers aided by self-assessment, industry/company/salary research, insider/expert advice, strategy and marketing tips, discussion boards and blogs, job listings, and job application; 2) specialized career sites where similar services are targeted to specific types of searches; 3) self-assessment tools where users can identify career interests, skills, personality, and needs and see what occupations/jobs may best match; and 4) other career resources.

Among full-service career sites to which sampled schools tend to provide access are www.collegegrad.com (College Grad), www.focuscareer.com (Focus), www.monster.com (Monster), www.quintcareers.com (Quintessential Careers), www.vault.com (Vault), and www.wetfeet.com (Wetfeet). Specialized career sites to which access tends to be provided by sampled schools include www.goingglobal.com (international jobs), www.peterson.com (graduate schools), www.gradschool.com (graduate schools), www.internship.com (internships), www.internships.com (internships), and www.usajobs.gov (U.S. federal government jobs).

Self-assessment tools to which online access tends to be provided by sampled schools include www.birkman.com (Birkman Method - for advanced/experienced students; identifies workplace interests, motivational needs, and stress behavior and matches that to optimal work environment), www.careerleader.com (Career Leader College - identifies workplace interests, skills, and reward values and compares that to those of professionals in various careers), www.discoveryourpersonality.com (Strong Interest Inventory/SII - identifies workplace interests and compares that with those of professionals in various fields), www.myersbriggs.org (MyersBriggs Type Indicator/MBTI - identifies personality/style and compares that with a corresponding list of occupations), and www.skillscan.net (Skill Scan - identifies workplace skills). 
Other career resources to which sampled schools tend to provide access include www.bls.gov/oco (Department of Labor Occupational Outlook Handbook), www.careertv.net (career resource videos and interactivity from WetFeet), InterviewTRAK (system for interview application, selection, and scheduling), www.jobhuntersbible.com (online counseling, testing, and advice supplementing Bolles' What Color is My Parachute), www.onetcenter.org (occupational requirements/skill sets ), www.optimalresume.com (career building modules including assessment, resume, cover letter, e-folio, video resume and interviewing), www.perfectinterview.com (interactive web-based interview skill building and virtual mock interview using webcam/upload), and www.payscale.com (salary comparisons).

The review of career centers at the sampled schools also found that individual schools of various rank have developed some initiatives that appear rather unique to them. They range from New York University's Business Boot Camp for liberal arts majors, to MIT's family weekend session on preparing students for the global economy, to University of Southern California's "innovatorship" internships with start-up companies. Appendix B itemizes these other career resources that are among those offered by individual schools sampled.

A measure of the impact on colleges and universities of career resources they provide is seen in Business Week's 2009 ranking of best undergraduate business schools. It found a decline in student satisfaction at more than half of the 101 schools it ranked; the rankings of schools that helped students navigate through the current job market increased the most. The top ranked schools put strong emphasis on career search guidance, in several cases moving out previously higher ranked schools whose student satisfaction comparatively dropped. For example, Business Week links University of Virginia's efforts to forge student-recruiter relations, resulting in three-quarters of its seniors having job offers, with its earning number one rank; Notre Dame's enlistment of alumni to locate jobs and advise students with its earning the number two spot; and Ohio State University's intense recruitment efforts with its rising 17 spots (Gloeckler, 2009).

\section{REPRESENTATIVE PRACTITIONER E-EMPLOYMENT INITIATIVES}

The literature discussed earlier reports that practitioners are also engaged in e-employment. A review of third party career websites ${ }^{7}$ and websites of companies identified by collegegrad.com as top entry level employers ${ }^{8}$ confirms and illustrates the range and quantity of that practitioner activity. The sampled third party career websites include those frequently included on the sampled college and university websites. Together, the third party career websites provide a potential employee with the equivalent of "one-stop shop" access to a spectrum of online career services including self-assessment, employment trends, skill requirements, salary information, marketing materials, networking, internship and full-time openings globally, qualification posting, job application including video/audio components, and comparative data on potential employers including testimonial by employees.

For their part sampled websites of top entry level employers both facilitate a potential employee gaining information relevant to his/her search, and extend the company's opportunity to attract a potential employee not actively seeking work who becomes interested in the company when finding career information on its website. Moreover, each of the sampled companies uses its website to individualize interaction with potential employees. They do so by using the second person direct address ("you"), value-added appeals (Progressive: "It's about you. And it's about time;" Enterprise: "It's like an MBA without the IOU;" IRS: "Career experiences that mean something more"), interactive program selectors matched to skills and interests (AmericCorps), and/or linkage to employees who through audio video segments tell about their jobs and the company (Target).

The literature on contemporary employment methods describes many initiatives also undertaken by practitioners as they infuse their screening activities with technology, as did the Pilot Study respondent describing his company's use of STARS. Goggle, for example, has used an online screening process to measure a candidate's attitude, behavior, personality, and biographical details. The candidate's answers are tallied applying a formula constructed to predict how well s/he is likely to perform the job applied for. AMC Entertainment's online application has included questions about a candidate's availability, work eligibility, desired pay, qualifications, and relevant awards; those whose answers do not screen them out proceed to an online interview containing 5-6 basic questions (Stafford, 2007). All-State Insurance has also used on-line questionnaires to screen candidates in or out; the in or out decision is made by comparing the candidate's scores to those of an ideal candidate, and the candidate 
is told at each stage if the match is sufficient for consideration to continue. J.P. Morgan Chase has learned about entry level worker's interests, attitudes, and abilities through an on-line game based on job-hunting and investment decisions (Cappelli, 2001).

The array of e-employment initiatives by practitioners includes outreach as well. Ernst \& Young, for instance, has distributed flash drives rather than print brochures about its company, given its interns video cams to create vlogs for the company website, and launched the first corporate-sponsored recruiting page on Facebook to meet potential Gen Y employees on their own turf (Hira, 2007). Boston Consulting Group and law firm Duane Morris LLP have used software to track employee communications to determine potential connections for it to pursue in other companies (King, 2006). Goldman Sachs and Deloitte have each run online alumni networks allowing them to find and rehire hiring former workers (King, 2006), as has New York Life Insurance. Some 8,000 former employees signed into New York Life Insurance's alumni network in its first month (Cappelli, 2001).

\section{FROM CHAT ROOM TO CLASS ROOM}

Conversations with fellow faculty members at two-year and four-year, public and private, colleges and universities find relatively common career-centered experiences with undergraduates. Students lacking career direction, more stressed by a perceived ever-more demanding job market, appear to regularly turn to career centers, faculty advisors, third party websites, family, peers, and career building modules of their classes for strategic guidance in how best to build the careers they are hoping to enter. This "chatting" generation tends to find questioning natural. But frequently today's Gen Y students claim in return to receive wide ranging though wellintentioned career building advice that is often contradictory, and worry that much of it may be dated. Many to whom students turn for career guidance are themselves uncertain as to whether they are sufficiently current to responsibly provide it. As a result, Table 5 summarizes some findings from data provided in this paper should those with undergraduate career building queries find it helpful.

Table 5: Some E-employment Basics for Today's College Students Seeking Employment

\begin{tabular}{|l|}
\hline $\begin{array}{l}\text { Interview, resume, observation, reference, portfolio/sample, testing, application form, and cover letter are widely used, and are } \\
\text { used in both traditional and electronic forms }\end{array}$ \\
\hline Traditional and electronic recruiting methods are in use \\
\hline Networking is a central route to employment \\
\hline $\begin{array}{l}\text { Communication skill, focus, initiative, interpersonal ability, leadership, maturity, professionalism, staying power, teamwork, } \\
\text { and work ethic are among valued attributes to convey }\end{array}$ \\
\hline Grades counts; aim to maintain a GPA of at least 3.0 \\
\hline Publically available material might be accessed by others; it should contain nothing considered private \\
\hline The virtual marketplace contains many pathways and is heavily trafficked \\
\hline Go online for self-assessment, self-marketing, industry/company/job data, and networking if it doable there \\
\hline Access face-to-face career services and networking as a foundation for and compliment to online career resources \\
\hline
\end{tabular}

\section{IMPLICATIONS FOR FUTURE RESEARCH}

Analysis of the existing literature raises several questions that are not readily answered and so have implications for future research. Literature does discuss the potential consequences of information overload for employer, for instance, but it does not as fully address the parallel quandary for potential employees. That is, while prior Gen X or Baby Boom undergraduates may have felt there was insufficient information to successfully enter the marketplace, today's Gen Y undergraduates may find themselves inversely daunted by when and what information to access and how to use what one has accessed. What "e-literacy" would be helpful? Is such training and guidance available?

Moreover, data makes it possible to identify traditional and employment methods being used. But the cost/benefit ratio of various methods is not as clear. Which employment methods would be recommended to potential employer and to potential employee based on valid outcomes assessment; which employment methods are most effective? 
Additionally, much of the online primary data is at this point self-reported. But how does the actual service delivered by a college or university career center, or the actual service delivered by a third party career website, or the employment experience described by a corporate website, compare to that which it states it provides?

Furthermore, the literature addresses legal and ethical issues regarding accessing and applying information that is publicly available online but not gathered directly from a candidate in employment activity. It does not as clearly address, though, the reality that a potential candidate can readily inflate material s/he distributes virtually about him/herself; and that s/he can readily distribute false negatives about others. How is such publicly available information to be validated?

Finally, career building and recruiting methods and strategies, and those using them, appear to be undergoing seismic shifts. Are those providing contemporary career services versed in these shifts? What impact will changing economic conditions have on the budgets of career service providers and recruiters, and their optimal strategies? Are providers and recruiters comfortable with and capable of adapting? Table 6 summarizes some resulting questions that may suggest areas for future research in this emerging, intricate, timely, and important field.

Table 6: Areas for Future Research

What e-employment literacy should potential employees have to optimize career building activity?

What traditional and electronic employment methods are most effective for employer? For employee?

How reliable is the information claimed on corporate, career service, and campus websites regarding the actual service/experience that is delivered?

How valid is publically available information distributed through primary sources regarding potential employer or potential employee?

Are there changes in qualifications and resources for those providing e-employment services and activities?

\section{CONCLUSION}

The literature and primary data reviewed for this paper report contemporary employment trends and an array of traditional and electronic employment methods currently in use by those engaged in U.S. employment activity. Existing literature suggests complex legal, ethical, and structural facets of a potential cyber global labor market that can seemingly network, be located, screen, and be screened in ways that redefine conventional boundaries. A key component of that labor market is increasingly the Gen Y college graduate, a member of a cohort group that frequents virtual reality by habit and choice, tends to lack career direction and desire career guidance, moves between jobs like it moves between websites to find career direction in the absence of guidance it finds sufficient, and confounds employers in so doing. Times are changing and uncertain on many dimensions for potential employer, would-be employee, and those seeking to provide them with career services.

If there is one certainty here, it may be that there is no quick fix to ensure sustainable career building and recruiting. On the other hand, there are clearly a host of traditional and electronic employment methods to consider, and ample identified practices upon which to draw. The current state of e-employment is aptly described by the state of Minnesota: "For every major job search strategy there's an Internet counterpart" (DEED, 2008). The opportunity and challenge for the longer term, though, is described by Cappelli: "On-line recruiting is more than just a human resources tool; it's a whole culture ... A new crop of workers will come to see the Internet as the only way to find a job" (2001).

En route today, identifying sustainable pathways would seem to be of heightened priority. By the start of 2009, an equal number of higher and lower income workers - nearly half of U.S. adults - were worried about becoming unemployed, and nearly three-quarters of U.S. adults knew someone who had lost a job in the last six months due to the economy (Superville, 2009). Some $90 \%$ of U.S. adults believed it to be a bad time to find a good job - the highest level of U.S. job market pessimism since it was first polled in October 2001 (Jacobe, 2009). By the end of 2009, close to 7 million jobs had been lost during the Great Recession. As the economy seeks to recover, an estimated quarter of a million U.S. jobs must be added each month just to keep pace with the rate of population growth (Labor Day by the Numbers, 2009). 


\section{AUTHOR INFORMATION}

Susan Eisner is a Professor of Management at Ramapo College of NJ. Prior to teaching she held key positions in a leading television station, prominent foundation, national political party, and Presidential campaign. Her graduate degree is from Harvard University, where she was an Administration Fellow. Her research/teaching interests include organizational behavior/management, business and society, career building, generational and gender diversity, and pedagogy. She has received the Thomases Award for Faculty Excellence (All-College), and the Outstanding Teacher Award (Business School). Among listings recognizing her achievements are Who's Who in the World, Who's Who in America, and Who's Who Among America's Teachers.

\section{REFERENCES}

1. $\quad$ Allen, P. (2004, September). Welcoming Y. Benefits Canada, 28 (9), 51 (3).

2. Aversa, J. (2009, January 9). Unemployment rate hits 16-year high. The Associated Press. Retrieved from http://money.aol.com.

3. Babcock, Pamela. (2007, December). Niche job sites gain market share. HR Magazine, p. 26, 28.

4. Baker, D. (2009, January 9). Economy loses 524,000 jobs in December unemployment rate hits 7.2\%. Washington D.C.: Center for Economic and Policy Research (CEPR).

5. Best colleges specialty rankings: Best undergraduate business programs. (2008, September 3). U.S. News \& World Report. Retrieved from http://colleges.usnews.rankingsandreviews.com/college/spec-business.

6. Borstorff et. al. P., Marker, M., and Bennett, D. (2007). Online recruitment: Attitudes and behaviors of job seekers. Journal of Strategic E-Commerce, 5 (1/2), p. 1-23.

7. Cappelli, P. (2001, March). Making the most of on-line recruiting. Harvard Business Review. R0103K.

8. Chao, G., and Gardner, P. (2007, Winter). Today's young adults: Surfing for the right job.

MonsterTrak.com and Michigan State University. Retrieved from http://ceri.msu.edu/publications.

9. Checking job sites increases among unemployed. (2009, February 26). The Associated Press. Retrieved from http://www.msnbc.com.

10. Collegerecruiter.com. (2006, March 26). Seven career networking tips for college students. Press Release. Retrieved from http://www.collegerecruiter.com.

11. Dohn, A., and Shniper, L. (2007, November). Employment outlook: 2006-2016: Occupational employment projections to 2016. Monthly Labor Review, 130 (11), p. 86-125. Washington D.C.

12. Educational Levels and Unemployment at the End of 2008. (2009, April 1). TED: The Editors Desk. Washington D.C.: Bureau of Labor Statistics. Retrieved from http://www.bls.gov.

13. Employment Situation Summary. (2010, January 8). Economic News Release. Washington D.C.: Bureau of Labor Statistics. Retrieved from http://www.bls.gov.

14. Employment Status of the Current Population 25 Years and Over by Educational Attainment. (2010, January 8). Economics News Release, Table A-4. Washington D.C.: Bureau of Labor Statistics. Retrieved from http://www.bls.gov.

15. For new college grads, cracking job market calls for marketing skills. (2008, September 30). New York Daily News.

16. Fountain, C. (2005, March). Finding a job in the Internet age. Social Forces, 83 (3), p. 1235-1262.

17. Gloeckler, G. (2009, March 1). The best undergrad business schools: BusinessWeek's fourth annual ranking reflects a treacherous job market. Business Week.

18. Hira, N. (2007, May 15). Attracting the twenty something worker. Fortune.

19. Hiring down, salaries up for interns and co-ops. (2009, March 20). News from NACE. Bethlehem PA: National Association of Colleges and Employers (NACE). Retrieved from http://www.naceweb.org.

20. Jacobe, D. (2009, February 20). Job-market pessimism reaches new high. The Gallup Poll.

21. King, R. (2006, September 11). Social networks: Executives use them too. Business Week.

22. Kleinfield, N. (2009, October 11). Jobs wanted, any jobs at all. The New York Times. Retrieved from http://www.nytimes.com.

23. Koc, E., and Collins, M. (2008, July 17). Are companies reaching candidates via social networking sites? Web Press Release. Bethlehem PA: National Association of Colleges and Employers (NACE). Retrieved from http://www.naceweb.org/press. 
24. Koncz, A., and Collins, M. (2008, March 7). Social networking sites gaining popularity among employers seeking job candidates. Web Press Release. Bethlehem PA: National Association of Colleges and Employers (NACE). Retrieved from http://www.naceweb.org/press.

25. Labor day by the numbers. (2009, September 7). EPI Fact Sheet. Washington D.C.: Economic Policy Institute. Retreived from http://www.epi.org

26. Luckenbaugh, C., and Collins, M. (2007, November 1). College career centers continue high-touch/hightech services to provide career and job-related services. Web Press Release. Bethlehem PA: National Association of Colleges and Employers (NACE). Retrieved from http://www.naceweb.org/press.

27. Millard, E. (2007, January). Online background checks. ABA Journal, 93, p. 37.

28. Minnesota DEED (Department of Employment and Economic Development). Internet job search strategies - The Internet job search. Minnesota: Saint Paul. Retrieved at http://www.deed.state.mn.us.

29. National Association of Colleges and Employers (NACE). (2009, March). Job outlook Spring update. Bethlehem PA. Retrieved from http://www.naceweb.org.

30. Noel-Levitz, Inc. (2007). Annual national freshman attitudes report. Retrieved from https://www.noellevitz.com.

31. Noel-Levitz, Inc. (2008). Annual national freshman attitudes report. Retrieved from https://www.noellevitz.com.

32. Piotrowski, C., and Armstrong, T. (2006, December). Current recruitment and selection practices. North America Journal of Psychology, 8 (3), p. 489-496.

33. Scroggins, W., Thomas, S., and Morris, J. (2008, Spring). Psychological testing in personnel selection. Public Personnel Management, 37 (1), p. 99-109.

34. Shin, A. (2009, January 4). College degree no shield as more jobs are slashed. The Washington Post, A01.

35. Society for Human Resource Management (SHRM). (2008, June). Workplace forecast. Washington D.C. Retrieved from http://www.shrm.org.

36. Sprague, R. (2007, Summer). Googling job applicants. The Labor Lawyer, 23 (1), p. 19-40.

37. Stafford, D. (2007, March 13). Don't update your resume - It's already a dinosaur. Knight Ridder Tribune News Service, p. 1.

38. Superville, D. (2009, February 19). Poll: Public fears about troubled economy growing. Associated Press. Retrieved at http://ww.ap.org.

39. The Internet brings risks/challenges to hiring. (2006, September). HR Focus, 83 (9), p. 5-7.

40. The present and future job market: Top trends \& how to prepare. (2006, June). HR Focus, 83.6.

41. The top undergraduate business programs. (2008, February 28). Business Week. Retrieved from http://bwnt.businessweek.com/interactive_reports/undergrad_bschool.

42. Uhalde, R. and Strohl, J. (2006. December). America in the global economy: A background paper for the Commission on the Skills of the American Workforce. Washington D.C.: National Center on Education and the Economy (NCEE). Retrieved from http://www.skillscommission.org (staff papers).

43. U.S. near full employment: White House. (2006, February 13). Reuters. Retrieved at http://www.redorbit.com.

44. Video resumes offer both pros and cons during recruiting. (2007, July). HR Focus, 84 (7), p.8.

45. Weiss, M. (2003, September 1) To be about to be (Generation Y). American Demographics, 25 (7).

46. What college grads can expect out of the job market. (2009, February 26). CNBC.com.

47. Workers naïve over online presence. (2007, December to 2008, January). Strategic Communication Management, 12 (1), p. 9.

\section{NOTES}

\footnotetext{
${ }^{1}$ Baby Boomers (the Baby Boom Generation) are generally viewed as being born $1945-1964$, and having some 80 million people in the U.S. Gen X (Generation X) is generally viewed as being born $1965-1980$, and having some 46 million people. Characteristics of Gen X, and Baby Boomers are detailed, along with those of the 75 million U.S. Traditionalists born before 1945 and those of the more than 76 million of U.S. Gen Y (Generation Y, see below) in Eisner, Susan. Managing generation y. SAM Advanced Management Journal. Vol. 07, Number 4. Autumn 2005, pp. 4-15.
} 


\footnotetext{
${ }^{2}$ Gen Y (also called Echo Boomers, Millenials, Internet Generation, or Nexters) is generally viewed as comprised by those born between 1980 and around 2000, and having more than 76 million people in the U.S. A commonly agreed upon end year for Gen $\mathrm{Y}$ awaits common agreement about the generation that follows it.
}

${ }^{3}$ Quantcast audience profiles of careerbuilder.com, collegegrad.com, facebook.com, linkedin.com, monster.com, myspace.com and vault.com for January 2009 were accessed from http://www.quamcast.com on February 22, 2009.

4 There were 14 schools included among the top 10 in either of the lists. As there were some differences in their order between the lists, the 10 highest ranked schools are identified here in alphabetical order: Brigham Young (Provo, Utah), Carnegie Mellon (Pittsburgh, Pennsylvania), Cornell (Ithaca, New York), Emory (Atlanta, Georgia), Massachusetts Institute of Technology (Cambridge), New York University (New York City), Notre Dame (Notre Dame, Indiana), University of California (Berkeley), University of Michigan (Ann Arbor), University of North Carolina (Charlotte), University of Pennsylvania (Philadelphia), University of Southern California (Los Angeles), University of Texas (Austin), and University of Virginia (Charlottesville). The 5 schools in the middle range of top ranked programs, in the order listed by Business Week from higher to lower, are University of Maryland (College Park), University of Georgia (Athens), Loyola (Baltimore, Maryland), University of Florida (Gainsville), and University of San Diego (California). The 10 schools in the bottom range of top ranked programs, identified in the order listed by Business Week from higher to lower, are University of Kentucky (Lexington), University of Arkansas (Fayetteville), Belmont (Nashville, Tennessee), Louisiana State (Baton Rouge), Loyola (Chicago, Illinois), University of Louisville (Kentucky), University of Tennessee (Knoxville), Temple University (Philadelphia, Pennsylvania), University of South Carolina (Columbia), and Iowa State (Aimes).

${ }^{5}$ The career service websites for the 29 schools sampled are (Arkansas) http://career.uark.edu, (Belmont) http://www.belmont.edu/careerservices, (Berkeley) http://career.berkeley.edu, (Brigham Young) http://ccc.byu.edu, (Carnegie Mellon) http://studentaffairs.cmu.edu/Career, (Cornell) http://www.career.cornell.edu, (Emory) http://www.career.emory.edu, (Florida) http://www.crc.ufl.edu, (Georgia) http://www.career.uga.edu, (Iowa State) http://www.career.iastate.edu (refers to individual schools for career services; career service for its business school is at http://www.business.iastate.edu/careers), (Kentucky) http://www.uky.edu/CareerCenter, (Louisiana State) http://www.lsu.edu/career, (Louisville) http://louisville.edu/career, (Loyola/Baltimore) http://loyola.edu/thecareercenter, (Loyola/Chicago) http://www.luc.edu/career, (Maryland) http://www.careercenter.umd.edu, (Michigan) http://www.careercenter.mich.edu, (MIT) http://web.mit/edu/career, (North Carolina) http://careers.unc.edu, (Notre Dame) http://careercenter.nd.edu, (NYU) http://ww.nyu.edu/careerdevelopment, (Pennsylvania) http://sww.vpul/upenn.edu/careerservices, (San Diego) http://www.sandiego.edu/careers, (South Carolina) http://www.sc.edu/career, (Southern California) http://career.usc.edu, (Temple) http://www.temple.edu/studentaffairs/careercenter, (Tennessee) http://career.utk.edu, (Texas) http://www.utexas.edu/student/careercenter, (Virginia) http://ww.career.virginia.edu

${ }^{6}$ Moore School of Business at University of South Carolina - Columbia.

${ }^{7}$ Career sites visited included www.birkman.com, www.bls.gov/oco, www.careerleader.com, www.careertv.net, www.collegegrad.com, www.discoveryourpersonality.com, www.focuscareer.com, www.focuscareer.com, www.goingglobal.com, www.internship.com, www.internships.com, www.jobhuntersbible.com, www.monster.com, www.onetcenter.org, www.optimalresume.com, www.payscale.com, www.perfectinterview.com, www.myersbriggs.org, www.quintcareers.com, www.skillscan.net, www.usajobs.gov, www.vault.com, and www.wetfeet.com.

${ }^{8}$ Websites of Progressive Auto Insurance (http://jobs.progressive.com), Target (http://sites.target.com), IRS (http://www.jobs,irs.gov), Americorps (http://www.americorps.org), and Enterprise Rent-A-Car (http://www.erac.com) were identified as representative top entry level employers for 2008 from the list and links at collegegrad.com (http://www.collegegrad.com/topemplyers); websites for each of those companies, and the career pages each company provided from its website homepage, were then visited. 


\begin{tabular}{|c|c|c|c|c|c|}
\hline \multicolumn{6}{|c|}{ APPENDIX A: Extent Skills Are Determined by Traditional and Electronic Employment Methods* } \\
\hline & $\begin{array}{c}\% 1 \\
\text { (very low use) }\end{array}$ & $\begin{array}{c}\% 2 \\
\text { (low use) }\end{array}$ & $\begin{array}{c}\% 3 \\
\text { (high use) }\end{array}$ & $\begin{array}{c}\% 4 \\
\text { (very high use) }\end{array}$ & $\begin{array}{c}\% 3+\% 4 \\
\text { (high+very high use) }\end{array}$ \\
\hline \multicolumn{6}{|l|}{ 1Application Form } \\
\hline T-paper & $16.67 \%$ & $25.00 \%$ & $16.67 \%$ & $41.67 \%$ & 58.34 \\
\hline E- online & $7.14 \%$ & $28.57 \%$ & $35.71 \%$ & $28.57 \%$ & 64.28 \\
\hline \multicolumn{6}{|l|}{2 Cover Letter } \\
\hline T- paper & $7.69 \%$ & $38.46 \%$ & $7.69 \%$ & $46.15 \%$ & 53.84 \\
\hline E- online & $0.00 \%$ & $42.86 \%$ & $21.43 \%$ & $35.71 \%$ & 57.14 \\
\hline \multicolumn{6}{|l|}{3 Interview } \\
\hline $\mathrm{T}$ - in person & $0.00 \%$ & $0.00 \%$ & $18.75 \%$ & $81.25 \%$ & 100.00 \\
\hline E- video & $15.38 \%$ & $38.46 \%$ & $46.15 \%$ & $0.00 \%$ & 46.15 \\
\hline E- phone & $7.14 \%$ & $28.57 \%$ & $35.71 \%$ & $28.57 \%$ & 64.28 \\
\hline E- email & $16.67 \%$ & $58.33 \%$ & $16.67 \%$ & $8.33 \%$ & 25.00 \\
\hline \multirow[t]{2}{*}{ E- instant message } & $36.36 \%$ & $36.36 \%$ & $0.00 \%$ & $27.27 \%$ & 27.27 \\
\hline & $\begin{array}{c}\% 1 \\
\text { (very low use) }\end{array}$ & $\begin{array}{c}\% 2 \\
\text { (low use) }\end{array}$ & $\begin{array}{c}\% 3 \\
\text { (high use) }\end{array}$ & $\begin{array}{c}\% 4 \\
\text { (very high use) }\end{array}$ & $\begin{array}{c}\% 3+\% 4 \\
\text { (high+very high use) }\end{array}$ \\
\hline \multicolumn{6}{|l|}{4 Observation } \\
\hline $\mathrm{T}$ - in person & $0.00 \%$ & $7.14 \%$ & $7.14 \%$ & $85.71 \%$ & 92.85 \\
\hline E-video & $16.67 \%$ & $25.00 \%$ & $58.33 \%$ & $0.00 \%$ & 58.33 \\
\hline \multicolumn{6}{|l|}{5 Portfolio/Sample } \\
\hline T- paper & $0.00 \%$ & $15.38 \%$ & $61.54 \%$ & $23.08 \%$ & 84.62 \\
\hline E- online & $7.69 \%$ & $7.69 \%$ & $76.92 \%$ & $7.69 \%$ & 84.61 \\
\hline$E-C D$ & $10.00 \%$ & $10.00 \%$ & $\overline{50.00 \%}$ & $30.00 \%$ & 80.00 \\
\hline \multicolumn{6}{|l|}{6 Reference } \\
\hline$\frac{0 \text { Reterence }}{\mathrm{T} \text { - paper }}$ & $0.00 \%$ & $21.43 \%$ & $21.43 \%$ & $57.14 \%$ & 78.57 \\
\hline$E$-video & $18.18 \%$ & $45.45 \%$ & $18.18 \%$ & $18.18 \%$ & 36.36 \\
\hline E-phone & $7.69 \%$ & $\overline{30.77 \%}$ & $15.38 \%$ & $46.15 \%$ & 61.53 \\
\hline E-email & $16.67 \%$ & $25.00 \%$ & $41.67 \%$ & $16.67 \%$ & 58.34 \\
\hline E-Instant Message & $50.00 \%$ & $20.00 \%$ & $10.00 \%$ & $20.00 \%$ & 30.00 \\
\hline \multicolumn{6}{|l|}{7 Resume } \\
\hline T- paper & $0.00 \%$ & $14.29 \%$ & $35.71 \%$ & $50.00 \%$ & 85.71 \\
\hline E- online & $0.00 \%$ & $6.25 \%$ & $31.25 \%$ & $62.50 \%$ & 93.75 \\
\hline \multicolumn{6}{|l|}{8 Testing } \\
\hline$T$ - paper & $9.09 \%$ & $27.27 \%$ & $45.45 \%$ & $18.18 \%$ & 63.63 \\
\hline E-online & $10.00 \%$ & $20.00 \%$ & $50.00 \%$ & $20.00 \%$ & 70.00 \\
\hline E- simulation & $11.11 \%$ & $22.22 \%$ & $44.44 \%$ & $22.22 \%$ & 66.66 \\
\hline
\end{tabular}

* In Appendix A, methods rated by 12 or fewer respondents are italicized, as their lower response rate suggests the use of these methods is less widespread among this study's sample companies. The most frequent response for each method is underlined, and majority responses are bolded. "T" indicates a traditional method, and "E" indicates an electronic method. 


\begin{tabular}{|c|c|}
\hline \multicolumn{2}{|c|}{ APPENDIX B: Other Career Resources at Top Rated Undergraduate Business Programs** } \\
\hline Schools & Representative Other Career Resources \\
\hline Brigham Young (1) & $\begin{array}{l}\text { Stress management lab; workshops include managing debt/finances, listening/comprehending/ note taking, } \\
\text { overcoming procrastination, time management }\end{array}$ \\
\hline Carnegie Mellon (1) & $\begin{array}{l}\text { Career success guide (step-by-step professional development/tools), cost of living, interview resources } \\
\text { (informational, etiquette/phone, and negotiating) }\end{array}$ \\
\hline Cornell (1) & $\begin{array}{l}\text { Career support in specific fields (health, law, public service), interactive counseling and testing guidance, } \\
\text { pursuing other options }\end{array}$ \\
\hline Emory (1) & $\begin{array}{l}\text { Career beam (research industry/company/people, plan and journal), career tv (global/interactive), career } \\
\text { values sort exercise }\end{array}$ \\
\hline MIT (1) & $\begin{array}{l}\text { Experiential/career learning workbook, family weekend session on preparing students for global economy, } \\
\text { internship network with } 8 \text { selective schools }\end{array}$ \\
\hline NYU (1) & $\begin{array}{l}\text { Business boot camp (liberal arts major), find us in Facebook, online networking developed by students, } \\
\text { virtual shadowing (frank look at jobs by workers) }\end{array}$ \\
\hline Notre Dame (1) & $\begin{array}{l}\text { Beyond on-campus recruiting (fairs/agencies off campus, fellowship, volunteer), featured internship, post- } \\
\text { college transitional behavior, work values checklist }\end{array}$ \\
\hline Berkeley (1) & $\begin{array}{l}\text { Decision scenarios for planning, email for field of interest, peer advisement, success story/profile, temporary } \\
\text { employment, video/podcast, who should attend }\end{array}$ \\
\hline Michigan (1) & $\begin{array}{l}\text { Alumni profiles, career support for pre-med/health/law, job search checklist, instant message advice (and in } \\
\text { person), video mock interview, workshop slides }\end{array}$ \\
\hline North Carolina (1) & $\begin{array}{l}\text { Business protocol, career clinic (identify skills/interests/values), draft/upload resume, tabs for students } \\
\text { undecided and those still searching, your public self }\end{array}$ \\
\hline Pennsylvania (1) & $\begin{array}{l}\text { Job search multiple company sites/non-profit work worldwide/government jobs, make most of winter break, } \\
\text { resources for students with protected characteristics }\end{array}$ \\
\hline $\begin{array}{l}\text { Southern } \\
\text { California (1) }\end{array}$ & $\begin{array}{l}\text { Career blog (work/career issues), innovatorship (intern at start ups), global fellowships, online career } \\
\text { information by major, podcasts, quick poll }\end{array}$ \\
\hline Texas (1) & $\begin{array}{l}\text { Faculty/staff contacts, links for specific majors/business sites/profiles, online ask a career pro, test } \\
\text { major/career choice, what are career tests/cost/result/option }\end{array}$ \\
\hline Virginia (1) & $\begin{array}{l}\text { Budget worksheet, career peer educators, email job opportunities by interest, how to start, what to do each } \\
\text { year, workbook analyzing work preferences }\end{array}$ \\
\hline Maryland (2) & $\begin{array}{l}\text { Gain experience/build skills: international (business/service/volunteer), intern, volunteer, extern, student } \\
\text { organization; international student jobs, quick bucks }\end{array}$ \\
\hline Georgia (2) & Career guide, hireUGA.com (link for employers looking to hire students/alum), video tip of the week \\
\hline $\begin{array}{l}\text { Loyola } \\
\text { (Baltimore) (2) }\end{array}$ & $\begin{array}{l}\text { International employment weekly, NACElink (access jobs, create/store resume apply online), prospective } \\
\text { student (first year/transfer), search graduate schools }\end{array}$ \\
\hline Florida (2) & $\begin{array}{l}\text { Career newsletter, career development for first generation and minority students, e-career counseling } \\
\text { (virtual chat), internships through chamber of commerce }\end{array}$ \\
\hline San Diego (2) & $\begin{array}{l}\text { Career planning guide for freshman/sophomore, links to career resource sites by field/major and to career } \\
\text { materials at other universities, online virtual career fair }\end{array}$ \\
\hline Kentucky (3) & $\begin{array}{l}\text { Database of alumni/employers/friends volunteering to network/mentor/shadow, link to find } \\
\text { counselor/career/major, year-by-year career planning timeline }\end{array}$ \\
\hline Arkansas (3) & $\begin{array}{l}\text { E-magazine with jobs, online guides include dreaded phone interview/your } 30 \text { second commercial/what } \\
\text { employers expect, professional development institute }\end{array}$ \\
\hline Belmont (3) & $\begin{array}{l}\text { Build customized career plan through assessment, experience, counseling, coaching; job search and graduate } \\
\text { school strategy/interview preparation }\end{array}$ \\
\hline Louisiana State (3) & $\begin{array}{l}\text { Informational interviewing tutorial, professional organizations/local networking events, searchable database } \\
\text { of alumni/friends who will share career advice }\end{array}$ \\
\hline $\begin{array}{l}\text { Loyola } \\
\text { (Chicago) (3) }\end{array}$ & $\begin{array}{l}\text { Career tv/job search videos, career transitions center, job search tools include dress for success and } \\
\text { correspondence guide, student code of conduct }\end{array}$ \\
\hline Louisville (3) & $\begin{array}{l}\text { Career management tools for all majors, business majors, or engineering majors who can search/apply for } \\
\text { part-time or full-time work on or off campus }\end{array}$ \\
\hline Tennessee (3) & $\begin{array}{l}\text { Careerspots.com videos include dressing for success/negotiating/researching, discussion boards re: career } \\
\text { management/marketing, virtual interviewing }\end{array}$ \\
\hline Temple (3) & $\begin{array}{l}\text { New state-of-art career center with on-site and virtual assess/counsel/coach resources, etiquette dinner, } \\
\text { online self-paced workshops, H1 visa jobs database }\end{array}$ \\
\hline South Carolina (3) & $\begin{array}{l}\text { 4-year list, brag (tell about new job), career interest game, tip sheets/videos, view (stand out in career fair); } \\
\text { business school classes/events per student's year }\end{array}$ \\
\hline Iowa State (3) & $\begin{array}{l}\text { GPA calculator, international programs, public affairs fellowship, relocation, service (e.g. americorps, peace } \\
\text { corps, teach for America), workinsports.com }\end{array}$ \\
\hline
\end{tabular}

